\title{
New Catalysts Based on Silicon Carbide Support for Improvements in the Sulfur Recovery. New Silicon Carbide Nanotubes as Catalyst Support for the Trickle-bed $\mathrm{H}_{2} \mathrm{~S}$ Oxidation
}

\author{
Nicolas Keller, Ricardo Vieira*, Jean-Mario Nhut, Cuong Pham-Huu and Marc J. Ledoux \\ Laboratoire des Matériaux, Surface et Procédés pour la Catalyse, Université Louis Pasteur, UMR 7515 CNRS, 25 rue \\ Becquerel, 67087 Strasbourg Cedex 2, France
}

\begin{abstract}
Nanotubos de carbeto de silício (SiC) foram preparados a partir da reação gás-sólido entre vapor de $\mathrm{SiO}$ e nanotubos de carbono. A fase ativa $\mathrm{NiS}_{2}$ suportada em nanotubos de $\mathrm{SiC}$ apresentou maior atividade catalítica e maior capacidade de armazenamento de enxofre na reação de oxidação seletiva do $\mathrm{H}_{2} \mathrm{~S}$ a enxofre elementar, em reator do tipo trickle-bed, que a mesma fase ativa suportada em grãos de $\mathrm{SiC}$. O melhor desempenho deste catalisador foi explicado pela ocorrência do efeito de confinamento no interior dos nanotubos de $\mathrm{SiC}$; ou seja, pelo aumento artificial da pressão parcial de $\mathrm{H}_{2} \mathrm{~S}$ no interior dos nanotubos em relação à mesma pressão fora dos nanotubos, resultando assim em um aumento na taxa da oxidação, uma vez que a velocidade de reação do $\mathrm{H}_{2} \mathrm{~S}$ é de primeira ordem. $\mathrm{O}$ catalisador suportado em nanotubos de $\mathrm{SiC}$ apresentou elevada resistência ao carregamento de enxofre devido a uma peculiar evacuação do enxofre pelo vapor de água condensado, permitindo assim uma limpeza contínua dos sítios ativos. A maior capacidade de armazenamento do enxofre sólido no suporte a base de nanotubos de $\mathrm{SiC}$ foi atribuído ao seu maior volume específico disponível para o armazenamento do enxofre do que o do suporte a base de grãos de SiC.
\end{abstract}

Silicon carbide nanotubes were prepared via a gas-solid reaction between $\mathrm{SiO}$ vapor and carbon nanotubes. The $\mathrm{NiS}_{2}$ active phase on this support displayed both a high catalytic activity and high solid sulfur storage capacity in the trickle-bed selective oxidation of $\mathrm{H}_{2} \mathrm{~S}$ into elemental sulfur as compared to the grain-based $\mathrm{SiC}$ catalyst. The hypothesis of a confinement effect inside the $\mathrm{SiC}$ nanotubes has been put forward to explain the catalytic results. An artificial increase in the $\mathrm{H}_{2} \mathrm{~S}$ partial pressure inside the tubes when compared to the $\mathrm{H}_{2} \mathrm{~S}$ partial pressure outside the tubes would lead to an increase in the oxidation rate, due to the first order reaction rate toward $\mathrm{H}_{2} \mathrm{~S}$. The $\mathrm{SiC}$ nanotube supported catalyst displayed very high resistance to the sulfur loading, due to a peculiar mode of sulfur evacuation by condensed steam which allows the continuous cleaning of the active site. The high solid sulfur storage capacity was due to a much larger void volume between each $\mathrm{SiC}$ nanotube available for the sulfur storage, than the void volume of $\mathrm{SiC}$ support with a grain size morphology.

Keywords: silicon carbide, nanotubes, $\mathrm{H}_{2} \mathrm{~S}$ oxidation, sulfur recovery, confinement effect

\section{Introduction}

The selective catalytic oxidation of $\mathrm{H}_{2} \mathrm{~S}$ by oxygen into elemental sulfur is the most interesting and efficient way for removing last traces of $\mathrm{H}_{2} \mathrm{~S}$ from waste acid gases generated by petrochemical refineries or natural gas plants. ${ }^{1,2}$ This reaction is of high environmental interest, due to the high toxicity of $\mathrm{H}_{2} \mathrm{~S}$. This reaction is also interesting from an economical point of view, leading to the transformation of a hazardous compound into a more valuable one for further chemical processes. The direct oxidation of $\mathrm{H}_{2} \mathrm{~S}$ into elemental sulfur has been developed,

\footnotetext{
* e-mail: vieirar@ecpm.u-strasbg.fr
}

in order to meet ever newer and stricter legislation requirements, that the well-known modified Claus process could not reach. ${ }^{1}$ Industrial processes and recent developments have been reported in Part I of the present paper and summarized in a series of reviews published in the literature. ${ }^{2,3}$ Previous works showed the very high performances obtained on silicon carbide grains or extrudates $(\mathrm{SiC})$ supported catalysts as compared to the literature and industrial catalysts, especially at the low temperature of $60{ }^{\circ} \mathrm{C} .^{4-7}$ The $\mathrm{H}_{2} \mathrm{~S}$ oxidation at low temperature is performed in a trickle-bed mode, the water of the inlet feed condensing at the head of the catalyst bed and trickling down through the catalyst. Such a tricklebed mode, close to a liquid-phase mode, led to consider 
that $\mathrm{SiC}$ nanotubes could be efficiently used as catalyst support compared to a macroscopic $\mathrm{SiC}$ support, by comparison with carbon nanotubes or nanofibers, which increase the catalytic efficiency when compared to carbon grains in liquid-phase applications. ${ }^{8}$

The aim of this article is to report the synthesis of $\mathrm{SiC}$ nanotubes via a gas-solid reaction. ${ }^{9-13}$ and their use as catalyst support for the trickle-bed oxidation of $\mathrm{H}_{2} \mathrm{~S}$ into elemental sulfur at $60{ }^{\circ} \mathrm{C}$.

\section{Experimental}

\section{Catalyst preparation}

Purified commercial multi-walled carbon nanotubes (MWNTs), supplied by Applied Science Ltd (Ohio, USA) were reacted with $\mathrm{SiO}$ vapor at $1200-1250{ }^{\circ} \mathrm{C}$, leading to the formation of $\mathrm{SiC}$ nanotubes. MWNTs were directly used without any pretreatment. They had mean inner and outer diameters of $c a .30 \mathrm{~nm}$ and $100 \mathrm{~nm}$, and lengths up to hundred micrometers. They showed a specific surface area of $20 \mathrm{~m}^{2} \mathrm{~g}^{-1}$ with no microporosity. Residual metallic iron with a concentration of $c a$. $0.2 \mathrm{wt}$. \%, previously used for the MWNTs synthesis, is encapsulated into the graphene layers, those particles thus being not accessible to the gas phase during any further treatments and reactions.

The $\mathrm{SiC}$ nanotubes obtained were calcined at $600{ }^{\circ} \mathrm{C}$ for $2 \mathrm{~h}$ in air to burn the remaining unreacted core carbon, as described by Keller et al. ${ }^{9}$ The nickel-based catalyst was prepared by incipient wetness impregnation of the $\mathrm{SiC}$ nanotube support with an aqueous solution of $\mathrm{Ni}\left(\mathrm{NO}_{3}\right)_{2} \cdot \mathrm{H}_{2} \mathrm{O}$ (Merck). It was dried at $120{ }^{\circ} \mathrm{C}$ for $14 \mathrm{~h}$ and then calcined at $350{ }^{\circ} \mathrm{C}$ for $2 \mathrm{~h}$ in order to decompose the nitrate salt and to form nickel oxide. The $\mathrm{SiC}$ nanotube supported $\mathrm{NiS}_{2}$ catalyst was obtained by sulfidation of its corresponding oxide by reaction with a $\mathrm{H}_{2} \mathrm{~S}(4 \mathrm{vol} . \%) / \mathrm{He}$ flow at $300{ }^{\circ} \mathrm{C}$ for $4 \mathrm{~h}\left(100 \mathrm{~mL} \mathrm{~min}^{-1}\right.$ for $5 \mathrm{~mL}$ of catalyst corresponding to a catalyst weight of $3.35 \mathrm{~g}$ ). The $\mathrm{NiS}_{2}$ nature of the supported phase after sulfidation has been determined by XRD. ${ }^{3}$ The loading of $\mathrm{Ni}$ was set at $5 \mathrm{wt}$. \% and confirmed by the atomic absorption spectroscopy technique, performed at the Service Central d'Analyse of the CNRS (Vernaison, France). It should be noted that the residual iron, i.e., ca. $0.2 \mathrm{wt}$ \%, coming from the starting MWNTs, was not active for the $\mathrm{H}_{2} \mathrm{~S}$ oxidation under the experimental conditions used.

\section{Micropilot description and characterization techniques}

The description of the $\mathrm{H}_{2} \mathrm{~S}$ oxidation set-up has been reported in the companion paper. ${ }^{3}$ The weight hourly space velocity (WHSV) was defined as the ratio of the inlet $\mathrm{H}_{2} \mathrm{~S}$ weight per hour to the weight of catalyst used.

Structural characterization of the samples was done by powder XRD measurements, carried out with a Siemens Diffractometer Model D-5000, using a $\mathrm{Cu} \mathrm{K}_{\alpha}$ radiation and operating at $40 \mathrm{kV}$ and $20 \mathrm{~mA}$. The nature of the crystalline phase in the sample was checked using the data base of the Joint Committee on Powder Diffraction Standards (JCPDS). Surface areas were measured by means of a commercial BET unit (Coulter Model SA 3100) using $\mathrm{N}_{2}$ adsorption at $-196^{\circ} \mathrm{C}$. The surface area was the surface calculated from the $\mathrm{N}_{2}$ isotherm using the BET method. The micropore content was obtained from the $t$-plot method in conjunction with the Harkins-Jura thickness equation. Scanning Electron Microscopy (SEM) was performed on a JEOL JMS840 working at $20 \mathrm{~mA}$ with an accelerating voltage of $20 \mathrm{kV}$.

\section{Results and Discussion}

\section{SiC nanotube synthesis}

The XRD pattern of the SiC nanotubes only displayed diffraction lines corresponding to $\mathrm{SiC}$ crystallized in the low temperature $\beta$-face centered cubic structure, together with the low angle peak assigned to the non reacted remaining carbon (Figure 1). No traces of silica or silicon were detected, meaning that such species, if present, were only in an amorphous form, in very small amounts or very highly dispersed. After calcination at $600{ }^{\circ} \mathrm{C}$ for $2 \mathrm{~h}$, the peak at low diffraction angles had disappeared and only

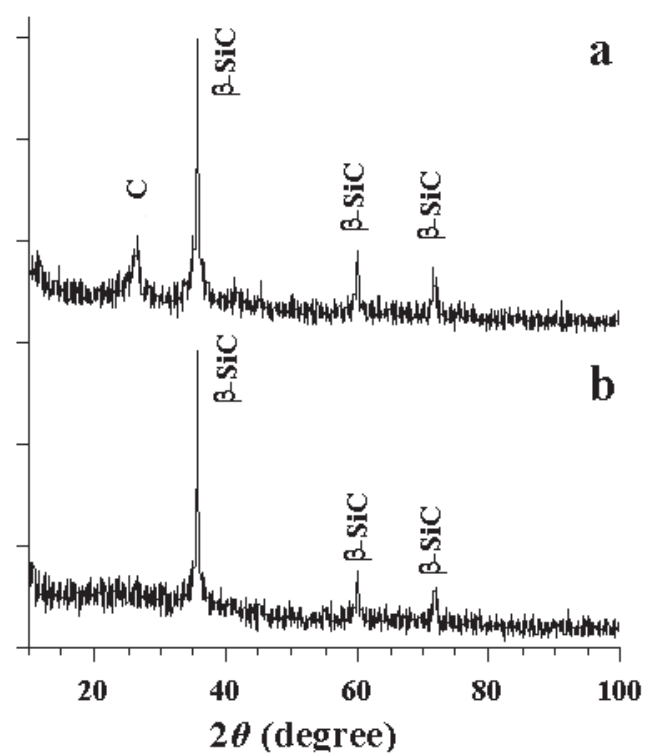

Figure 1. XRD patterns of the $\mathrm{SiC}$ nanotubes (a) as-synthesized and (b) after air treatment at $600^{\circ} \mathrm{C}$ for $2 \mathrm{~h}$ to remove the remaining unreacted carbon. 
diffraction lines corresponding to $\mathrm{SiC}$ were observed. The $\mathrm{SiC}$ conversion could be tuned by adjusting the reaction conditions. Typical conversion of $c a .80 \mathrm{wt}$. $\%$ were obtained. This was explained by the carburization mechanism, i.e., the well-known Shrinking Core Model, which states that the reacional interface is maximum at the beginning of the transformation and then regularly decreases as the reaction proceeds. ${ }^{14,15}$ The formation, as a function of the transformation course, of $\mathrm{SiC}$ layers on the carbon surface, acting as a diffusion barrier for $\mathrm{SiO}$ and $\mathrm{CO}$ vapors, led to a progressive decrease in the rate of carburization.

The $\mathrm{C}$ to $\mathrm{SiC}$ transformation was accompanied by an increase in the specific surface area, from $20 \mathrm{~m}^{2} \mathrm{~g}^{-1}$ up to ca. $40-50 \mathrm{~m}^{2} \mathrm{~g}^{-1}$. The $\mathrm{SiC}$ nanotubes synthesized had no microporosity. The increase in specific surface when going from carbon to $\mathrm{SiC}$ nanotubes was attributed to $(i)$ the formation of a new porosity and (ii) the change in density during the transformation. The loss of one carbon atom as $\mathrm{CO}$ gas along with the density difference (between carbon and $\mathrm{SiC}$ ) when going from $\mathrm{C}$ to $\mathrm{SiC}$ was probably responsible for the specific surface area increase, by formation of a new porosity, by the creation of voids and channels during the escape of $\mathrm{CO}$ molecules from the material. Similar results have already been reported during the study of $\mathrm{SiC}$ microtube synthesis starting from the low surface area and non-porous graphite filaments using the same synthesis method. ${ }^{9}$ Volpe and Boudart have reported similar observations during the vapor phase carburization of solid $\mathrm{MoO}_{3} \cdot{ }^{16}$ The oxide to carbide transformation was accompanied by an important increase in the specific surface area due to the change in the density and specific volume of the carbide when compared to its oxidic parent.

Figure 2 shows the SEM images of the starting carbon nanotubes and the corresponding $\mathrm{SiC}$ nanotubes. The general tubular morphology of the carbon precursor was completely retained after the carburization process, which highlighted the efficiency and the advantage of the SMS method in the conservation of the starting shape of the carbon material. It should be noted that the smooth surface of the MWNTs was transformed after carburisation into a more roughness one where holes and cracks can be visualized, in close agreement with the increase in surface area. No closure of the tube tip occurred during the synthesis, both inner and outer surfaces of the tubes also remaining accessible for further treatments. The $\mathrm{SiC}$ nanotubes had mean inner and outer diameters of $\mathrm{ca} .30$ and $100 \mathrm{~nm}$ respectively.

\section{Oxidation of $\mathrm{H}_{2} \mathrm{~S}$ in a trickle-bed mode}

Previous works showed that $\mathrm{NiS}_{2}$ supported on $\mathrm{SiC}$
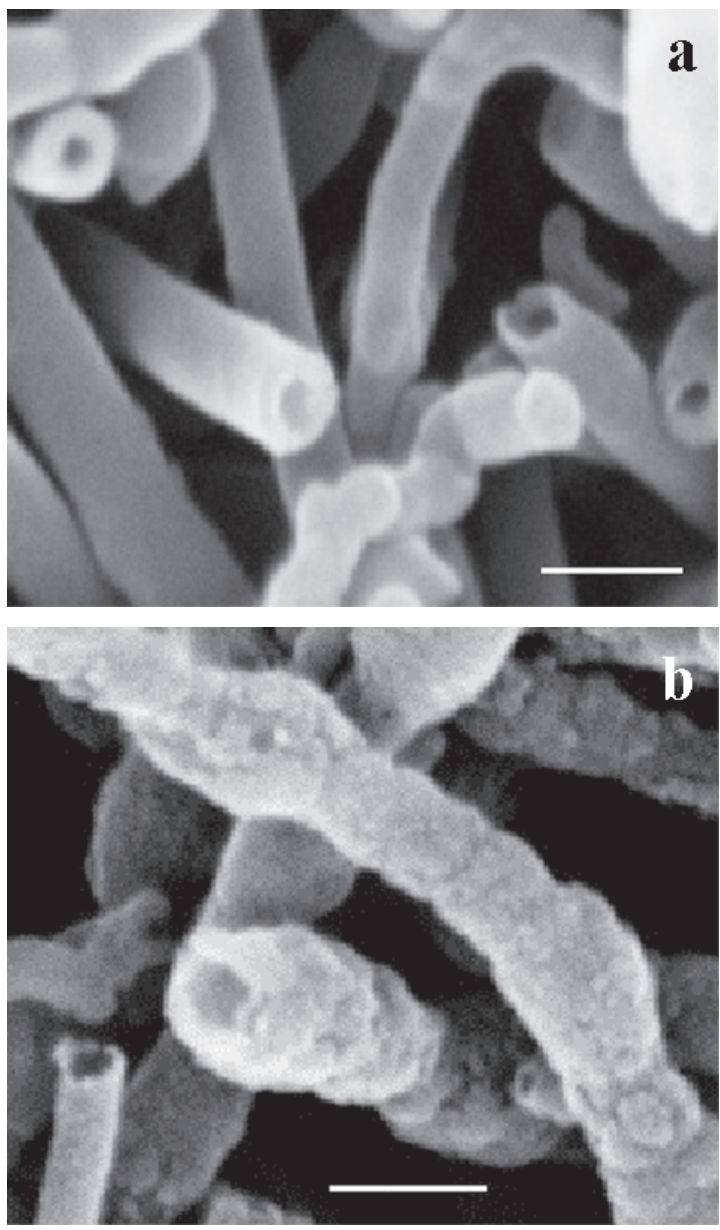

Figure 2. SEM images of carbon (a) and SiC (b) nanotubes. The scale bars represent $100 \mathrm{~nm}$.

grains displayed, for a velocity of $0.007 \mathrm{~h}^{-1}, \mathrm{a} \mathrm{H}_{2} \mathrm{~S}$ conversion of $100 \%$ since the beginning of the test and for more than $100 \mathrm{~h}$ of time on stream. ${ }^{3,6}$ Such a high performance for the selective $\mathrm{H}_{2} \mathrm{~S}$ oxidation was notably due to the mechanical removal of the sulfur formed from the active sites by a water film. The role of condensed water, acting as a conveyor belt on the catalyst surface when using $\mathrm{SiC}$ grains has already been reported and discussed in details. ${ }^{3,13,17}$ A liquid water film allowed the sulfur formed to be removed from the $\mathrm{NiS}_{2}$ active sites before the subsequent storage on hydrophobic SiC surfaces, outside the pores, which are free of active phase.

Performing the test at higher velocity $\left(0.02 \mathrm{~h}^{-1}\right)$ in the present study, led to a completely different behavior of the catalyst in terms of activity (Figure 3). A few hour activation period was observed on the catalyst supported on $\mathrm{SiC}$ grains, attributed to the time required by the $\mathrm{NiS}_{2}$ phase to be superficially transformed into a new active phase, an oxysulfide phase formed by the oxygen-sulfur exchange. ${ }^{6,17}$ It should be noted that the catalyst rapidly deactivated as 
a function of time on stream. This was attributed to the high space velocity and to the blockade of the active sites by the solid sulfur deposit. The transport phenomenon by water seemed to be insufficient at a high space velocity and thus, the solid sulfur formed remains on the active sites leading to deactivation by encapsulation.

Figure 3 shows the benefit use of $\mathrm{SiC}$ nanotubes as support for the $\mathrm{NiS}_{2}$ phase. At a WHSV of $0.02 \mathrm{~h}^{-1}$, the $\mathrm{SiC}$ nanotube supported catalyst still exhibited a $\mathrm{H}_{2} \mathrm{~S}$ conversion of $100 \%$ since the beginning of the test and no deactivation was observed, even for more than $100 \mathrm{~h}$ of time on stream, for which the weight of accumulated solid sulfur on the material became greater than $200 \mathrm{wt}$. \% of the starting weight of the catalyst. The absence of any visible activation period at the beginning of the test was attributed to a higher $\mathrm{H}_{2} \mathrm{~S}$ oxidation rate, which resulted from the tubular morphology of the catalyst. The sulfur selectivity remained at $100 \%$ in good agreement with the low reaction temperature. ${ }^{6,17,18}$

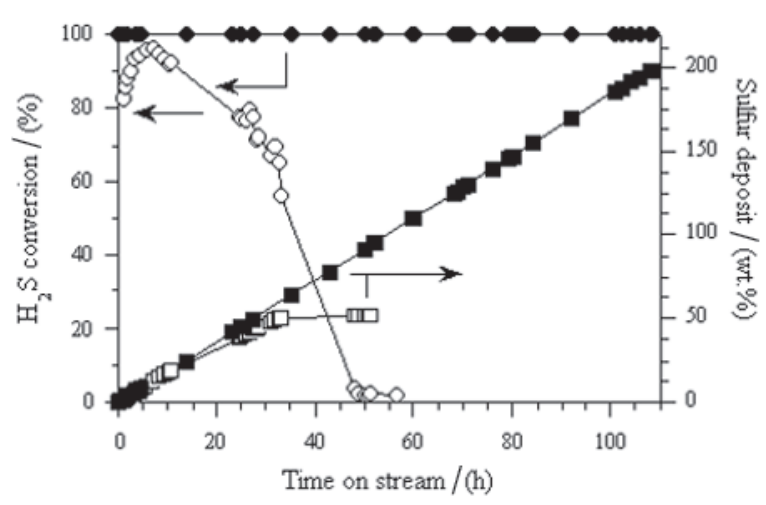

Figure 3. $\mathrm{H}_{2} \mathrm{~S}$ conversion and the corresponding solid sulfur deposit on the surface as a function of time on stream at $60{ }^{\circ} \mathrm{C}$ obtained for WHSV $=0.02 \mathrm{~h}^{-1}$ with the $\mathrm{SiC}$ nanotubes (filled symbols) and the $\mathrm{SiC}$ grains (empty symbols) as support. $\left(\mathrm{H}_{2} \mathrm{~S}=2000 \mathrm{ppm}\right.$ vol., $\mathrm{O}_{2}=$ 3200 ppm vol., $\mathrm{H}_{2} \mathrm{O}=20 \%$ vol., balance $\mathrm{He}, \mathrm{O}_{2} / \mathrm{H}_{2} \mathrm{~S}=1.6$, catalyst weight $=3.35 \mathrm{~g}$, WHSV $\left.=0.02 \mathrm{~h}^{-1}\right)$.

It should be noted that most of the $\mathrm{NiO}$ phase, and also after the sulfidation step, its corresponding $\mathrm{NiS}_{2}$ phase, was located inside the $\mathrm{SiC}$ nanotubes: TEM images only showed few $\mathrm{NiO}$ particles onto the outer walls of the tubes (not reported). The thickness of $\mathrm{SiC}$ rendered the material too much absorbent for electrons, and did also not allow the direct observation of nickel-based phases inside the tubes. EDS carried out on isolated $\mathrm{SiC}$ nanotubes proved however the presence of nickel inside the tubules (not reported). It was worth noting that the use of $\mathrm{SiC}$ nanotubes allowed to significantly improve both activity of the catalyst and the solid sulfur storage capacity for the low temperature oxidation of hydrogen sulfide. The impro- vement in the storage capacity of the catalyst was attributed to the increase in the free volume of the nanotube material, which remained available for the sulfur storage during the reaction, when compared to the traditional grain size material. Taking into account that the void volume outside the tubes is much larger than outside the pores of usual mesoporous $\mathrm{SiC}$ grains, after the evacuation of solid sulfur outside the nanotubes by water, according to the same conveyor belt process, larger amounts of sulfur could also be stored in the external void volume, where only very few $\mathrm{NiS}_{2}$ particles are located.

Figure 4 shows a SEM image of the active $\mathrm{SiC}$ nanotube supported $\mathrm{NiS}_{2}$ catalyst after test and loaded with $200 \mathrm{wt}$. $\%$ of solid sulfur. Presence of solid sulfur outside the SiC tubes was clearly evidenced, although only very few particles of active phase was found on the outer walls of the catalyst as previously reported above. The sulfur having been formed where the reaction took place, i.e., on the $\mathrm{NiS}_{2}$ phase inside the nanotubes, one can assume that sulfur formed inside the $\mathrm{SiC}$ tubules was transported and then stored outside the tubular structure.

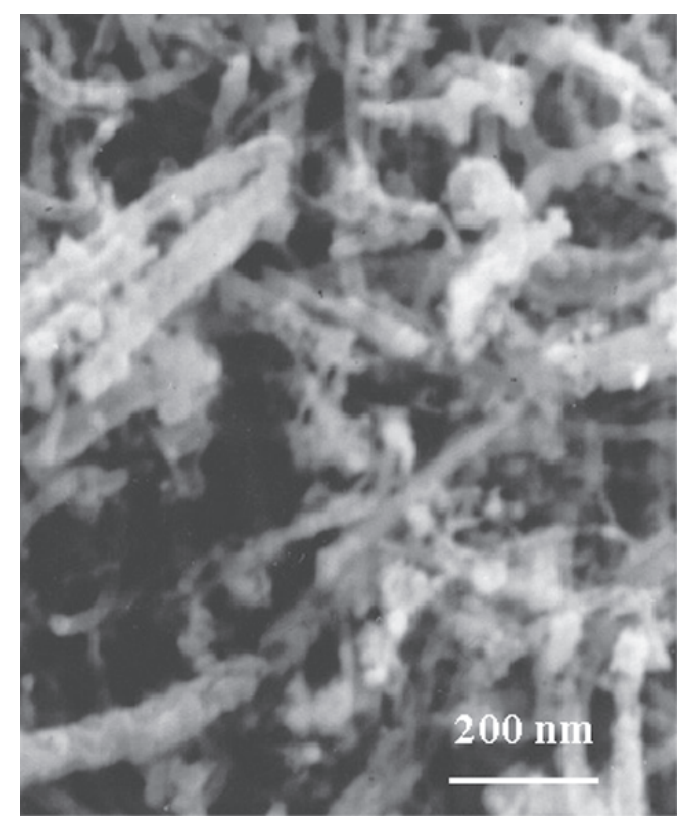

Figure 4. SEM image of the 200 wt. \% sulfur loaded SiC nanotubebased catalyst after $100 \mathrm{~h}$ on stream at $60{ }^{\circ} \mathrm{C}$.

\section{The confinement effect}

Baker and co-workers ${ }^{19}$ proposed that the peculiar activity obtained for graphite nanofiber supported nickel catalysts for the hydrogenation of butadiene or crotonaldehyde was due to the specific morphology adopted by the nickel phase and induced by the strong interactions with the nanofiber support. Using a very 
different kind of support, i.e., $\mathrm{SiC}$ nanotubes, we had in the present study no evidence of the flat hexagonal morphology observed on graphite nanofibers by Baker and co-workers. In addition, the mean $\mathrm{NiS}_{2}$ particle size inside the $\mathrm{SiC}$ nanotubes was estimated at about $20 \mathrm{~nm}$ by the XRD peak broadening method of Scherrer, similar to what was both observed by TEM and derived from the Scherrer technique on the $\mathrm{NiS}_{2} / \mathrm{SiC}$ grains catalyst. No difference in the $\mathrm{NiS}_{2}$ dispersion could be proposed. It appeared also interesting to develop a new idea, in order to explain the gain in activity when using the nanotube morphology as support : the inner partial pressure concept, or confinement effect due to the peculiar tubular morphology of the material.

The increase in WHSV led to a significant decrease in the $\mathrm{H}_{2} \mathrm{~S}$ conversion on the catalyst supported on $\mathrm{SiC}$ grains. Pieplu et al. ${ }^{20}$ recently summarized in an extended review kinetic studies related to the direct and selective $\mathrm{H}_{2} \mathrm{~S}$ oxidation by $\mathrm{O}_{2}$ to elemental sulfur. According to a traditional rate law with positive reaction order relative to $\mathrm{H}_{2} \mathrm{~S}$, the increase in WHSV would be compensated by an increase in the $\mathrm{H}_{2} \mathrm{~S}$ partial pressure on the catalytic sites, in order to maintain the initial reaction rate, i.e., $\mathrm{H}_{2} \mathrm{~S}$ conversion. It led to the development of a confinement concept in order to explain the observed results.

The inner partial pressure concept is based on the large increase of the $\mathrm{H}_{2} \mathrm{~S}$ partial pressure inside the $\mathrm{SiC}$ nanotubes, probably by microcapillarity phenomenon. In this concept, the apparent macroscopic $\mathrm{H}_{2} \mathrm{~S}$ partial pressure, outside the nanotubes, would remain unchanged, whereas the microscopic or nanoscopic partial pressure would significantly increase inside the nanostructure. Such a modification of the reactant partial pressure could probably occur during the flow through the tube, due to a tube wall effect and segregation phenomena between the different gaseous products. According to such a concept, one would expect that compounds with a high dipolar moment, i.e., $\mathrm{H}_{2} \mathrm{~S}$ which is the less concentrated one among the reactants, would be the most affected during the diffusion through the tubule. A similar concept has been proposed by different authors such as Dillon et al. ${ }^{21}$ and Liu et al. ${ }^{22}$ for use of carbon nanotubes to improve hydrogen storage capacities. In the present study, the use of $\mathrm{SiC}$ instead of carbon and of $\mathrm{H}_{2} \mathrm{~S}$ as inlet reactant, a molecule presenting a permanent dipole, instead of more "inert" $\mathrm{H}_{2}$ molecules in term of interactions with the surface, would both lead to more visible effects than in the works cited above. Concerning the nature of the used nanotubes, it is probable that the hydrophilic oxygen-containing surface layer was also formed during the synthesis of the $\mathrm{SiC}$ nanotubes. The carbon nanofiber to $\mathrm{SiC}$ nanotube transformation, along with the nanostructure opening, could even favored such a partial oxidation of the inner $\mathrm{SiC}$ layer, due to the probable high defect density of the inner $\mathrm{SiC}$ nanotube surface. The highly hydrophilic nature of the nanotube inner surface would also increase the microcapillarity phenomenon.

\section{Conclusions}

Medium surface area $\beta$-SiC nanotubes prepared according to the Shape Memory Synthesis method was very successfully used as support material for the $\mathrm{NiS}_{2}$ based active phase for the trickle-bed oxidation of $\mathrm{H}_{2} \mathrm{~S}$ into elemental sulfur at $60{ }^{\circ} \mathrm{C}$. SiC nanotubes had mean inner and outer diameters of ca. 30 and $100 \mathrm{~nm}$. The use of $\mathrm{SiC}$ nanotubes led to a significant increase in the overall catalytic performance, both in terms of activity and resistance to the solid sulfur deposition onto the material as compared to the reference catalyst supported on macroscopic SiC grains. The hypothesis of a confinement effect inside the $\mathrm{SiC}$ nanotubes has been advanced to explain the gain in activity observed. This confinement effect would lead to an increase in the partial pressure of $\mathrm{H}_{2} \mathrm{~S}$ inside the tubes compared to that outside the tubes which remained unchanged. The high capacity of solid sulfur storage on the material compared to that of macroscopic SiC grains has been explained by the large void volume outside the nanotubes when compared to the void volume outside of usual mesoporous and macroporous $\mathrm{SiC}$ grains.

\section{Acknowledgements}

This work was financially supported by Elf Aquitaine (France) and Lurgi Oil (Germany). RV is indebted to CNPq (Brazil) and Sicat (France) for the support and financial resources.

\section{References}

1. Estep, J. W.; McBride Jr. G. T.; West, J. R.; Advances in Petroleum Chemistry and Refining, vol.6, Interscience: New York, 1962, ch 7.

2. Wieckowska, J.; Catal. Today 1995, 24, 405.

3. Keller, N.; Vieira, R.; Nhut, J. M.; N.; Pham-Huu, C.; Ledoux, M. J.; J. Braz. Chem. Soc. 2004, in press.

4. Ledoux, M. J.; Nougayrède, J. B.; Savin-Poncet, S.; PhamHuu, C.; Keller, N.; Crouzet, C.; French pat. 97-16617, 1997.

5. Ledoux, M. J.; Pham-Huu, C.; Keller, N.; Savin-Poncet, S.; Nougayrède, J. B.; Bousquet, J.; Catal. Today 1999, 53, 535.

6. Keller, N.; Pham-Huu, C.; Estournès, C.; Ledoux, M. J., Appl. Catal. A 2002, 234, 193. 
7. Keller, N.; Pham-Huu, C.; Ledoux, M. J.; Appl. Catal. A 2001, 217, 205.

8. Pham-Huu, C.; Keller, N.; Ledoux, M. J.; Charbonnière, L.J.; Ziessel, R.; J. Mol. Catal. A 2001, 170, 155.

9. Keller, N.; Pham-Huu, C.; Ledoux, M. J.; Estournès, C.; Ehret, G., Appl. Catal. A 1999, 187, 255.

10. Ledoux, M. J.; Guille, J. L.; Hantzer, S.; Dubots, D.; US pat. 4 $914070,1990$.

11. Ledoux, M. J.; Pham-Huu, C.; Chianelli, R. R.; Curr. Opin. Solid State Mater. Sci. 1996, 1, 96.

12. Keller, N.; Pham-Huu, C.; Roy, S.; Ledoux, M. J.; Estournès, C.; Guille, J.; J. Mater. Sci. 1999, 34, 3189.

13. Ledoux, M. J.; Pham-Huu, C.; CaTTech 2001, 5, 226

14. Hurst, N. W.; Gentry, S. J.; Jones, A.; McNicol, B. D.; Catal. Rev.-Sci. Eng. 1982, 24, 233.

15. Falconer, J. L.; Schwartz K. A.; Catal. Rev.-Sci. Eng. 1983, 25, 141.
16. Volpe, L; Boudard, M.; J. Solid State Chem. 1985, 33, 332.

17. Ledoux, M. J., Pham-Huu, C.; Keller, N.; Nougayrède, J. B.; Savin-Poncet, S.; Bousquet, J.; Catal. Today 2000, 61,157.

18. Klein, J.; Henning, H. D.; Fuel 1984, 63,1064.

19. Chambers, A.; Nemes, T.; Rodriguez, N. M.; Baker, R. T. K; J. Phys. Chem. B 1998, 102, 2251.

20. Pieplu, A.; Saur, O.; Lavalley, J. C.; Catal. Rev. Sci. Eng. 1998, 40, 409.

21. Dillon, A. C.; Jones, K. M.; Bekkedahl, T. A.; Klang, C. H.; Bethune, D. S.; Heben, M. J.; Nature 1997, 386, 377.

22. Liu, C.; Fan, Y. Y.; Liu, M.; Cong, M. T.; Cheng, H. M.; Dresselhaus, M. S.; Science 1999, 286, 1127.

Received: December 10, 2003 Published on the web: February 21, 2005 